\title{
Structure and composition study of carbon-doped titanium oxide film combined with first principles
}

\author{
Wei $\mathrm{MAI}^{a}$, Feng $\mathrm{WEN}^{a,{ }^{*}}$, Dong $\mathrm{XIE}^{b}$, Yongxiang $\mathrm{LENG}^{b}$, Zhonglin $\mathrm{MU}^{c}$ \\ ${ }^{a}$ Key Lab of Advanced Materials of Tropical Island Resources of Ministry of Education, School of Materials and \\ Chemical Engineering, Hainan University, Haikou 570228, P.R.China \\ ${ }^{b}$ Key Lab of Advanced Technologies of Materials, Ministry of Education, Chengdu 610031, P.R.China \\ ${ }^{c}$ Hainan Medical University, Haikou 571199, P.R.China
}

Received: October 23, 2013; Revised: January 04, 2014; Accepted: January 08, 2014

(CThe Author(s) 2014. This article is published with open access at Springerlink.com

\begin{abstract}
Carbon-doped titanium oxide (C/Ti-O) films were prepared on $\mathrm{Si}(100)$ wafer, stainless steel (type 304) and glass by reactive magnetron sputtering (RMS) using $\mathrm{CO}_{2}$ gas as carbon and oxygen source under room temperature (RT). X-ray diffraction (XRD) and X-ray photoelectron spectroscopy (XPS) were used to analyze structure and composition of the as-prepared C/Ti-O film. It could be observed from XRD that the as-prepared $\mathrm{C} / \mathrm{Ti}-\mathrm{O}$ film contained TiO crystal phase structure. Ti2p XPS spectrum of the as-prepared $\mathrm{C} / \mathrm{Ti}-\mathrm{O}$ film showed that the valences of titanium were made up of $\mathrm{Ti}^{2+}, \mathrm{Ti}^{3+}$ and $\mathrm{Ti}^{4+}$. C1s XPS spectrum revealed that carbon was doped into titanium oxide based on the existence of the typical Ti-C bond. The optical absorption curve by ultraviolet-visible (UV-Vis) spectrophotometer showed that the $\mathrm{C} / \mathrm{Ti}-\mathrm{O}$ film appeared the remarkable red shift of absorption edge, which contributed to $\mathrm{C}$ substitution in $\mathrm{O}$ sites in amorphous $\mathrm{TiO}_{2}$. Photocatalysis test using methyl orange (MO) as indicator confirmed that the as-prepared $\mathrm{C} / \mathrm{Ti}-\mathrm{O}$ film had photocatalytic activity. Combined with the results of the tests and first-principles calculations, a potential photocatalysis mechanism was proposed.
\end{abstract}

Keywords: $\quad \mathrm{C} / \mathrm{Ti}-\mathrm{O}$ films; carbon-doped; magnetron sputtering; first principles

\section{Introduction}

$\mathrm{TiO}_{2}$ as a promising semiconductor material has received intense attention for environmental cleaning, water splitting and solar cells due to its low cost, nontoxicity, long-term stability and high oxidative power [1-3]. However, $\mathrm{TiO}_{2}$ used as photocatalyst shows photoactivity only under ultraviolet (UV) light due to its large intrinsic energy band gap $\left(E_{\mathrm{g}}=3.2 \mathrm{eV}\right)$

* Corresponding author.

E-mail: fwen323@163.com
[4]. Furthermore, the recombination of photogenerated electron-hole pair is relatively easy in $\mathrm{TiO}_{2}$. Therefore, many attempts have been made to improve the photocatalytic efficiency of $\mathrm{TiO}_{2}$ in order to overcome the UV limitation and extend the optical absorption of $\mathrm{TiO}_{2}$ to the visible-light region, involving doping other chemical elements $[5,6]$, semiconductor compounding [7] and dye sensitizing [8].

As a result, nonmetal doping, such as $\mathrm{N}$ [9], $\mathrm{C}$ [10], $\mathrm{F}$ [11], $\mathrm{S}$ and $\mathrm{P}$ [12], has been extensively investigated. Wang et al. [13] prepared a C-doped $\mathrm{TiO}_{2}$ catalyst 
using a nonhydrolytic sol-gel method and found that substitutional and interstitial carbon atoms coexist in the lattice of $\mathrm{TiO}_{2}$. Yang et al. [14] found the surface area of the $\mathrm{C}$ and $\mathrm{N}$ co-doped $\mathrm{TiO}_{2}$-based photocatalyst is increased, and the photocatalytic efficiency is enhanced. Unfortunately, the previous modification studies were based on crystalline $\mathrm{TiO}_{2}$, and little attention has been paid to amorphous $\mathrm{TiO}_{2}$ because it is commonly accepted that amorphous $\mathrm{TiO}_{2}$ contains high concentration of defects, which can function as rapid electron-hole pair recombination centers rendering them inactive [15]. Hence, there have been only few studies and reports of amorphous $\mathrm{TiO}_{2}$ [16-19], especially amorphous $\mathrm{TiO}_{2}$ with $\mathrm{TiO}$ crystal phase.

In this study, carbon-doped titanium oxide ( $\mathrm{C} / \mathrm{Ti}-\mathrm{O})$ films were synthesized by reactive magnetron sputtering (RMS) using $\mathrm{CO}_{2}$ as carbon and oxygen source under room temperature (RT). Structure and composition of the $\mathrm{C} / \mathrm{Ti}-\mathrm{O}$ film were studied by the analysis of X-ray diffraction (XRD) and X-ray photoelectron spectroscopy (XPS). Optical absorption characteristic of the $\mathrm{C} / \mathrm{Ti}-\mathrm{O}$ film was measured by UV-Vis spectrophotometer. Combined with firstprinciples calculations, the potential photocatalysis mechanism of the $\mathrm{C} / \mathrm{Ti}-\mathrm{O}$ film was proposed.

\section{Experiment}

\section{1 Film preparation and characterization}

The $\mathrm{C} / \mathrm{Ti}-\mathrm{O}$ films were prepared on $\mathrm{Si}(100)$ wafer and stainless steel (type 304) by RMS, discharging Ar and $\mathrm{CO}_{2}$ gas mixture (the ratio of $\mathrm{Ar} / \mathrm{CO}_{2}$ was $60 \mathrm{sccm}$ to

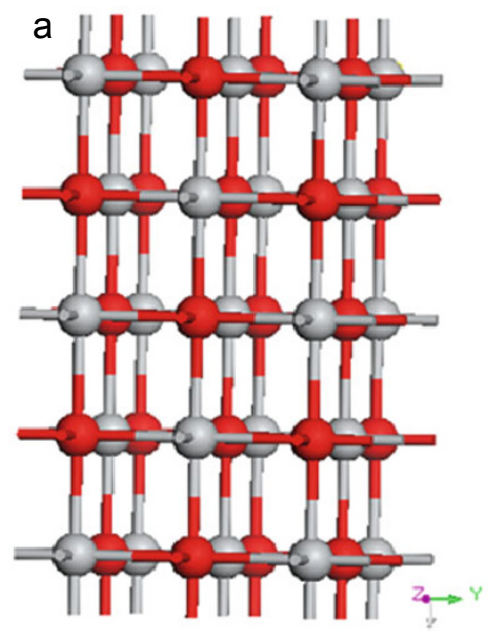

$18 \mathrm{sccm}$ ) and using high-purity titanium (99.99\%) as titanium plasma source under RT. The $\mathrm{C} / \mathrm{Ti}-\mathrm{O}$ film was also prepared on glass for absorbance measurement.

The microstructure of the $\mathrm{C} / \mathrm{Ti}-\mathrm{O}$ film was measured by XRD (X'Pert Pro MPD, Philips, the Netherlands) using glancing diffraction method with an incident angle of $\theta=0.5^{\circ}$. The chemical composition of the $\mathrm{C} / \mathrm{Ti}-\mathrm{O}$ film was determined using XPS (Type K-ALPHA, Thermo Electron Corporation, USA). Absorbance is a very important property for assessing photocatalysis. The absorbance of the as-prepared $\mathrm{C} / \mathrm{Ti}-\mathrm{O}$ film was measured by UV-Vis spectrophotometer (type TU-1810) in the wavelength range of 250-900 nm.

Photocatalytic activity of the $\mathrm{C} / \mathrm{Ti}-\mathrm{O}$ film was also evaluated by the degradation test of methyl orange (MO) under UV light irradiation. During the photo-degradation test, the $\mathrm{C} / \mathrm{Ti}-\mathrm{O}$ film was placed into the MO solution $(10 \mathrm{mg} / \mathrm{L})$ loaded in a dish. A 15 -W bactericidal lamp as UV source was placed on the top of the dish with the spacing between the light bulb and the surface of the dish being $34 \mathrm{~cm}$. The concentration of MO in solution was measured during an interval of time by monitoring the absorbance at $464 \mathrm{~nm}$ on the UV-Vis spectrophotometer. The degradation of reactant could be calculated by

$$
\eta(\%)=\frac{c_{0}-c}{c_{0}} \times 100
$$

where $c_{0}$ is the initial concentration of MO; $c$ is the concentration of MO after $t$-min irradiation.

\section{2 Models and methods of calculation}

Figure 1 shows the supercell structures of crystalline

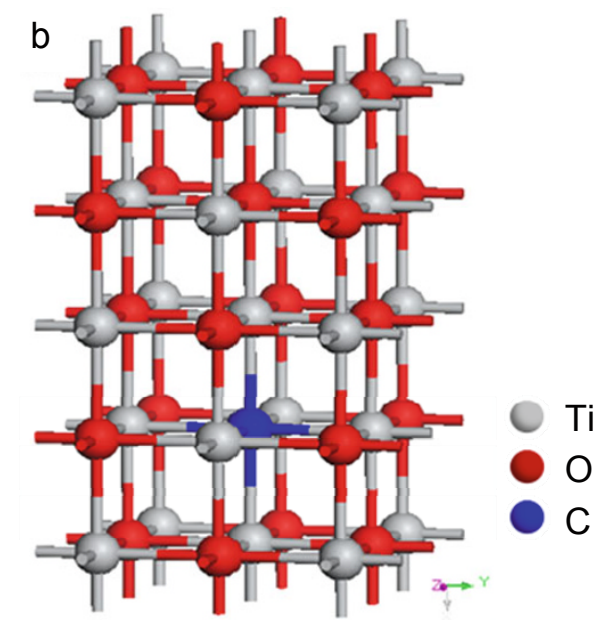

Fig. 1 The supercell structures of (a) TiO and (b) C-doped TiO. 
$\mathrm{TiO}(\mathrm{TiO})$ and $\mathrm{C}$-doped $\mathrm{TiO}$, respectively. $\mathrm{TiO}$ has a body-centered cubic structure with $a=4.1766 \AA$ [20]. Supercells built of $2 \times 1 \times 1$ unit cells were used in the calculations for undoped (Fig. 1(a)) and substitutional doped systems (Fig. 1(b)). For the C-doped TiO model, an $\mathrm{O}$ atom $(0.25,0.50,0.50)$ was replaced by a $\mathrm{C}$ atom. The units of pure $\mathrm{TiO}$ and $\mathrm{C}$-doped $\mathrm{TiO}$ were optimized employing the CASTEP module of Materials Studio 5.0 developed by Accelrys. The total plane-wave pseudopotential method forms the basis of the CASTEP calculations. The electronic exchange correlation energy was treated under the generalized gradient approximation (GGA) with the Perdew-Burke-Ernzerhof method. The plane-wave based cut-off energy was set at 340 for $\mathrm{TiO}$ and C-doped TiO. The Monkhorst-Packschemek point grid sampling was set at $7 \times 7 \times 7$ for the Brillouin zone. All convergence parameters were set as follows: total energy tolerance of $1.0 \times 10^{-5} \mathrm{eV} /$ atom, maximum force tolerance of $0.03 \mathrm{eV} / \mathrm{nm}$ and maximum stress component of $0.05 \mathrm{GPa}$. After geometry optimization, band structure, total density of states (DOS) and partial density of states (PDOS) were calculated.

\section{Results and discussion}

\section{1 Microstructure}

Figure 2 is the XRD pattern of the as-prepared $\mathrm{C} / \mathrm{Ti}-\mathrm{O}$ film on $\mathrm{Si}(100)$ wafer. In Fig. 2, the diffraction peaks corresponding to (100), (200), (220), (311) and (222) crystal planes of $\mathrm{TiO}$ are observed. The small-angle X-ray scattering (SAXS) pattern matches well with the standard powder diffraction data (JCPDS No. 08-0117). Zhang et al. [21] and Martin et al. [22] found that the anatase and rutile phases coexist in the films when a

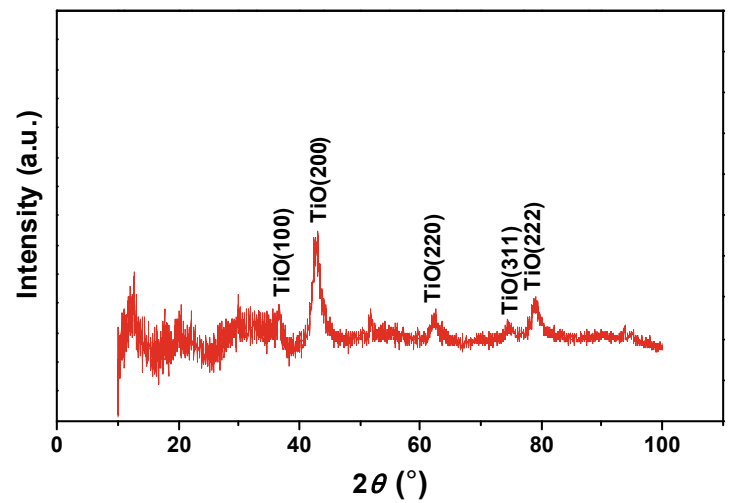

Fig. 2 XRD pattern of the $\mathrm{C} / \mathrm{Ti}-\mathrm{O}$ film in a grazing angle configuration $\left(\theta=0.5^{\circ}\right)$. target of titanium $(99.995 \%)$ and a mixture of argon and oxygen gases are used to deposit $\mathrm{TiO}_{2}$ films on $\mathrm{Si}(100)$ wafers. However, no observable peak of rutile or anatase $\mathrm{TiO}_{2}$ is observed in the $\mathrm{C} / \mathrm{Ti}-\mathrm{O}$ film, which indicates the incorporated $\mathrm{C}$ in the as-prepared $\mathrm{C} / \mathrm{Ti}-\mathrm{O}$ film inhibits the formation of rutile or anatase phase [23].

\section{2 Chemical composition}

XPS is quite sensitive to the characteristics of the film surface, because the non-elastic scattering mean free path $\lambda_{\mathrm{m}}$ of emitted photoelectron is very short [24]. Figure 3 is the C1s and Ti2p XPS spectra of the $\mathrm{C} / \mathrm{Ti}-\mathrm{O}$ film after etching for $30 \mathrm{~s}$ in order to eliminate the effect of the surface absorption. The $\mathrm{C} 1 \mathrm{~s}$ spectrum could be deconvoluted into two peaks by Gaussian fitting and approximating the contribution of background by the smart mode at about $282.0 \mathrm{eV}$ and $284.6 \mathrm{eV}$ as shown in Fig. 3(a). The peak at $284.6 \mathrm{eV}$ is usually attributed to the adventitious carbon or carbon residues from the organic precursor (mainly $\mathrm{C}-\mathrm{C}$ bond) $[25,26]$. The additional peak located at $282.0 \mathrm{eV}$ is attributed to the $\mathrm{Ti}-\mathrm{C}$ bond resulting from the substitution of oxygen atoms by carbon, which indicates carbon is doped into titanium oxide lattice
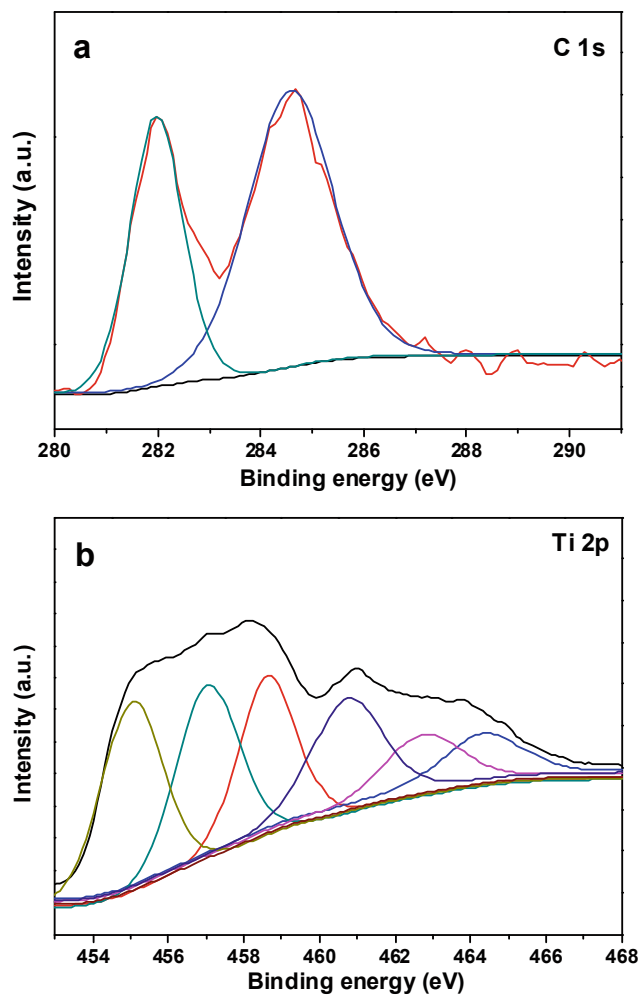

Fig. 3 XPS spectra of amorphous $\mathrm{TiO}_{2}$ composite: (a) $\mathrm{C} 1 \mathrm{~s}$ peaks, (b) Ti2p peaks. 
successfully. The high-resolution XPS spectrum of Ti2p is illustrated in Fig. 3(b). $\mathrm{Ti}^{4+}$ species are indicated by binding energies of $459.3 \mathrm{eV}$ (Ti2p3/2) and $464.6 \mathrm{eV}(\mathrm{Ti} 2 \mathrm{p} 1 / 2)$, those of $\mathrm{Ti}^{3+}$ species are located at about $456.7 \mathrm{eV}$ (Ti2p3/2) and $462.5 \mathrm{eV}$ (Ti2p1/2), and those of $\mathrm{Ti}^{2+}$ species are located at about $455.4 \mathrm{eV}(\mathrm{Ti} 2 \mathrm{p} 3 / 2)$ and $461.1 \mathrm{eV}(\mathrm{Ti} 2 \mathrm{p} 1 / 2)$ [27]. The binding energy difference

$$
\Delta E_{\mathrm{b}}=E_{\mathrm{b}}(\operatorname{Ti} 2 \mathrm{p} 1 / 2)-E_{\mathrm{b}}(\operatorname{Ti} 2 \mathrm{p} 3 / 2)
$$

is always close to $5.7 \mathrm{eV}$, which indicates the standard binding energy for Ti element [28]. Figure 3(b) shows the content of $\mathrm{Ti}^{4+}$ and $\mathrm{Ti}^{3+}$ is relatively high, but the corresponding crystal structures of $\mathrm{Ti}^{4+}$ and $\mathrm{Ti}^{3+}$ are not observed in Fig. 2(b), which suggests that amorphous $\mathrm{TiO}_{2}$ and $\mathrm{Ti}_{2} \mathrm{O}_{3}$ exist in the as-prepared $\mathrm{C} / \mathrm{Ti}-\mathrm{O}$ film, or the content of $\mathrm{TiO}_{2}$ and $\mathrm{Ti}_{2} \mathrm{O}_{3}$ crystal phase is little. Suriye et al. [29] reported that $\mathrm{TiO}_{2}$ surface defects $\left(\mathrm{Ti}^{3+}\right)$ play significant role as they are active sites for oxygen adsorption and for trapping the electron to prevent the recombination of electrons and holes. Hamdy et al. [30] also reported that surface $\mathrm{Ti}^{3+}$ sites provide the unique activity and selectivity in the target reactions at relatively high wavelengths. Detailed theoretical explanations are described in Refs. $[31,32]$. Thus, $\mathrm{TiO}$, amorphous $\mathrm{TiO}_{2}$ and $\mathrm{Ti}_{2} \mathrm{O}_{3}$ exist in the as-prepared $\mathrm{C} / \mathrm{Ti}-\mathrm{O}$ film by the analysis of XRD and XPS.

\section{3 Absorbance}

The optical absorption characteristic of the $\mathrm{C} / \mathrm{Ti}-\mathrm{O}$ film is shown in Fig. 4. The absorbance of $\mathrm{P} 25\left(\mathrm{TiO}_{2}\right)$ is also measured as a comparison as shown in Fig. 4. It could be observed obviously from Fig. 4 that the $\mathrm{C} / \mathrm{Ti}-\mathrm{O}$ film exhibits more remarkable red shift towards visible-light region as compared to $\mathrm{P} 25\left(\mathrm{TiO}_{2}\right)$, which could be attributed to the $\mathrm{C} 2 \mathrm{p}$ impurity states created by carbon incorporated into amorphous $\mathrm{TiO}_{2}$ [33]. To estimate the optical band gap $E_{\mathrm{g}}$, a Tauc's plot is constructed in which the absorption coefficient $A$ is plotted against the photon energy $E$ as follows:

$$
(A E)^{1 / 2}=B\left(E-E_{\mathrm{g}}\right)
$$

where $B$ is a proportionality constant. The optical band gap $E_{\mathrm{g}}$ can be deduced from the intercept of the extrapolated straight line with the $E$ axis as shown in Fig. 4(b). The band gap of the $\mathrm{C} / \mathrm{Ti}-\mathrm{O}$ film is only $2.44 \mathrm{eV}$ which is much smaller than the band gap of $\mathrm{P} 25\left(\mathrm{TiO}_{2}\right)$ of $2.95 \mathrm{eV}$.
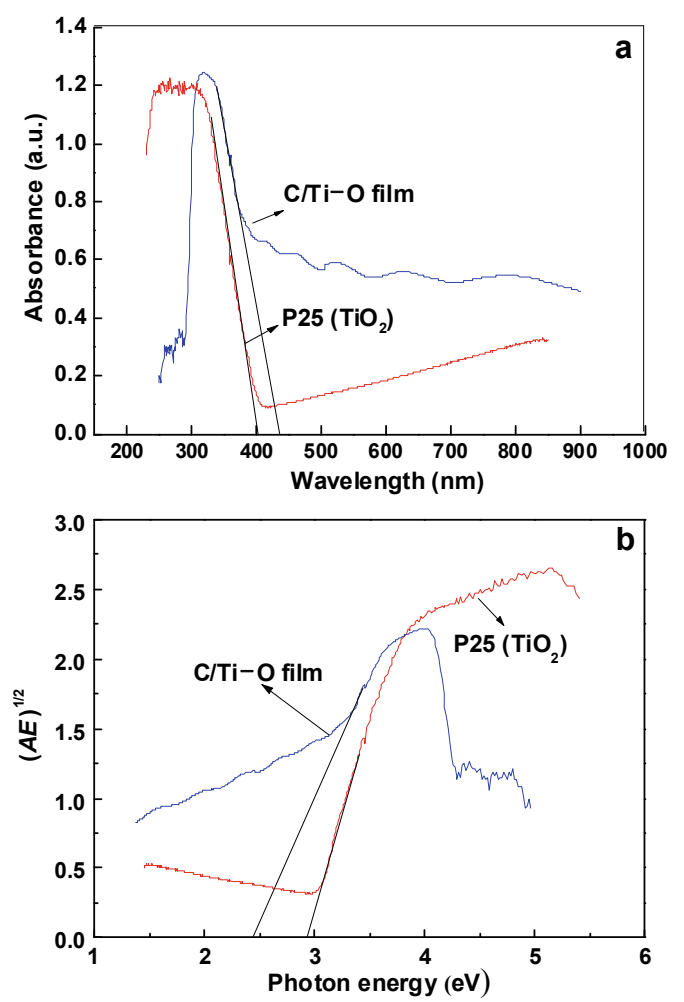

Fig. 4 UV-Vis diffusion reflectance spectra of the $\mathrm{C} / \mathrm{Ti}-\mathrm{O}$ film and $\mathrm{P} 25\left(\mathrm{TiO}_{2}\right)$ : (a) absorbance versus wavelength and (b) absorption coefficient versus photo energy.

\section{4 Photocatalytic experiment}

Figure 5 shows the photoactivity of the $\mathrm{C} / \mathrm{Ti}-\mathrm{O}$ film that is evaluated by heterogeneous degradation of MO waste water under UV irradiation in different time at RT. It is obviously observed that the $\mathrm{C} / \mathrm{Ti}-\mathrm{O}$ film shows some photocatalytic activity. When the $\mathrm{C} / \mathrm{Ti}-\mathrm{O}$ film placed into the MO solution is irradiated for 480

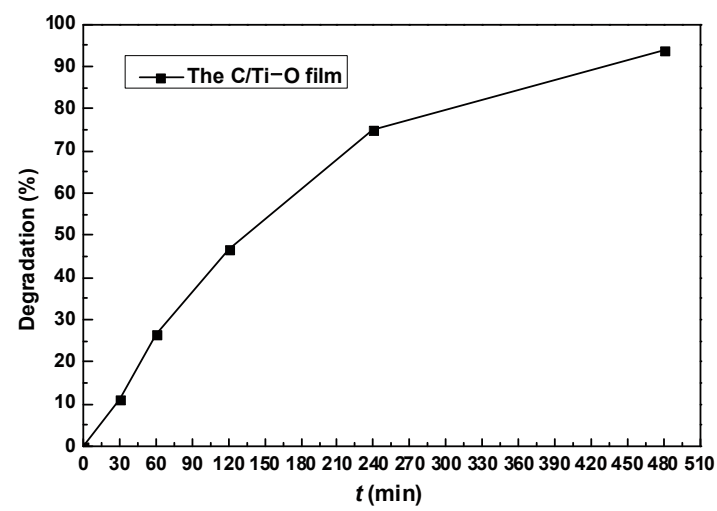

Fig. 5 MO degradation curve using the $\mathrm{C} / \mathrm{Ti}-\mathrm{O}$ film synthesized on stainless steel (type 304) under UV irradiation. 
min, the degradation percentage of MO reached to 94\%. However, amorphous $\mathrm{TiO}_{2}$ has long been reported to be nearly inactive due to the facilitated recombination of photo-generated electrons and holes under UV light irradiation [15], which indicates the recombination of photo-generated electrons and holes are restrained. The further explanation is made in the following passage.

\section{5 Photocatalysis mechanism}

In order to analyze the photocatalysis mechanism of the $\mathrm{C} / \mathrm{Ti}-\mathrm{O}$ film, electronic properties of $\mathrm{TiO}$ and C-doped $\mathrm{TiO}$ due to $\mathrm{TiO}$ crystal phase existed in the as-prepared $\mathrm{C} / \mathrm{Ti}-\mathrm{O}$ film are analyzed using Materials Studio software based on first principles. The calculated energy band structures of the models are showed in Fig. 6. Wang et al. [20] reported that $\mathrm{TiO}$ is metallic. As shown in Fig. 6(b), approximate parabolic energy levels of the conduction band pass across Fermi level, and the change of the levels has no obvious difference near Fermi level regardless of $\mathrm{C}$ doping or not doping, which indicates $\mathrm{C}$-doped $\mathrm{TiO}$ is also metallic. As compared to Fig. 6(a), the valence band and conduction band are found to be relatively wider and some impurity levels are only observed near Fermi energy in Fig. 6(b), which implies C-doped TiO could form the new states for shallow impurity levels. To further understand how the band gap changes, the DOS and PDOS of TiO and C-doped TiO models are calculated as shown in Fig. 7. In Fig. 7(b), the conduction band and valence band of C-doped $\mathrm{TiO}$ are mainly dominated by the Ti3d and O2p orbitals near Fermi level, respectively. And the states across the Fermi energy are mostly Ti3d states, which are consistent with those of $\mathrm{TiO}$. Hence, $\mathrm{C}$-doped $\mathrm{TiO}$ is metallic. In addition, it is found that there is the overlap of Ti3d states and a small amount of C2p states, which contributes to the impurity levels.

Figure 8 gives the potential photocatalysis mechanism of the as-prepared $\mathrm{C} / \mathrm{Ti}-\mathrm{O}$ film with $\mathrm{TiO}$ crystal phase under visible-light irradiation. On one hand, C-doping makes the band gap of amorphous $\mathrm{TiO}_{2}$ decrease and appear the red shift of absorption edge. On the other hand, C-doped $\mathrm{TiO}$ as metal load of amorphous $\mathrm{TiO}_{2}$ surface participates in transferring the photoproduction electronics from the $\mathrm{CB}$ of $\mathrm{C}$-doped $\mathrm{TiO}_{2}$ [34]. This phenomenon benefits the separation of electrons and holes. Hence, the $\mathrm{C} / \mathrm{Ti}-\mathrm{O}$ film with $\mathrm{TiO}$ crystal phase has the photocatalytic activity.
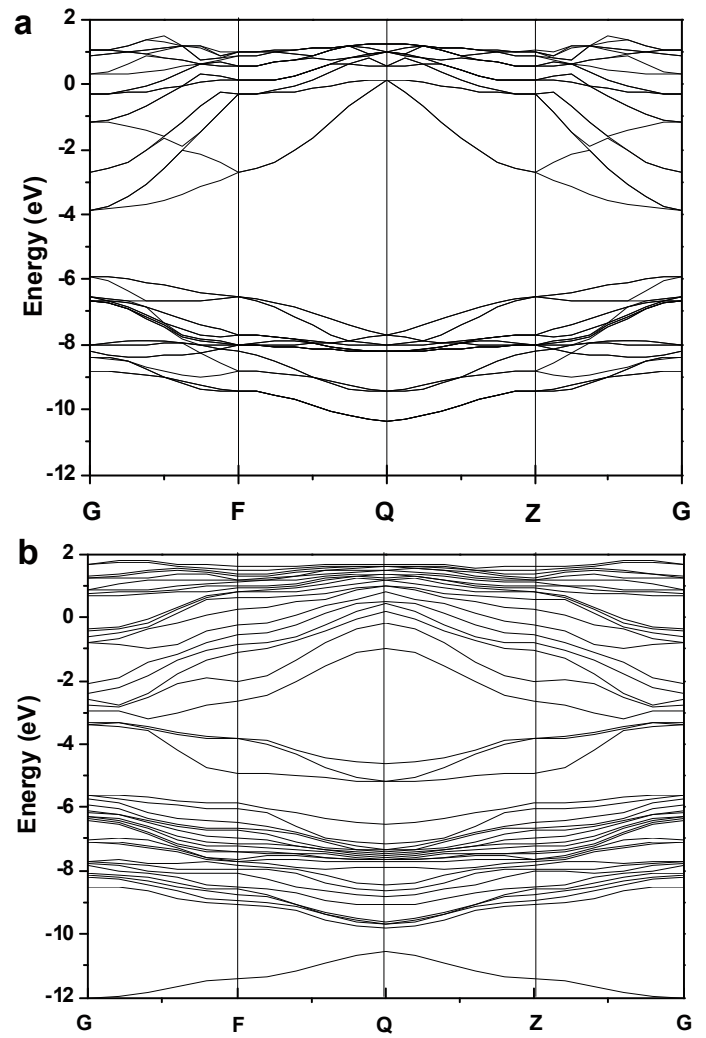

Fig. 6 Calculated band structures for (a) $\mathrm{TiO}$ and (b) C-doped TiO.
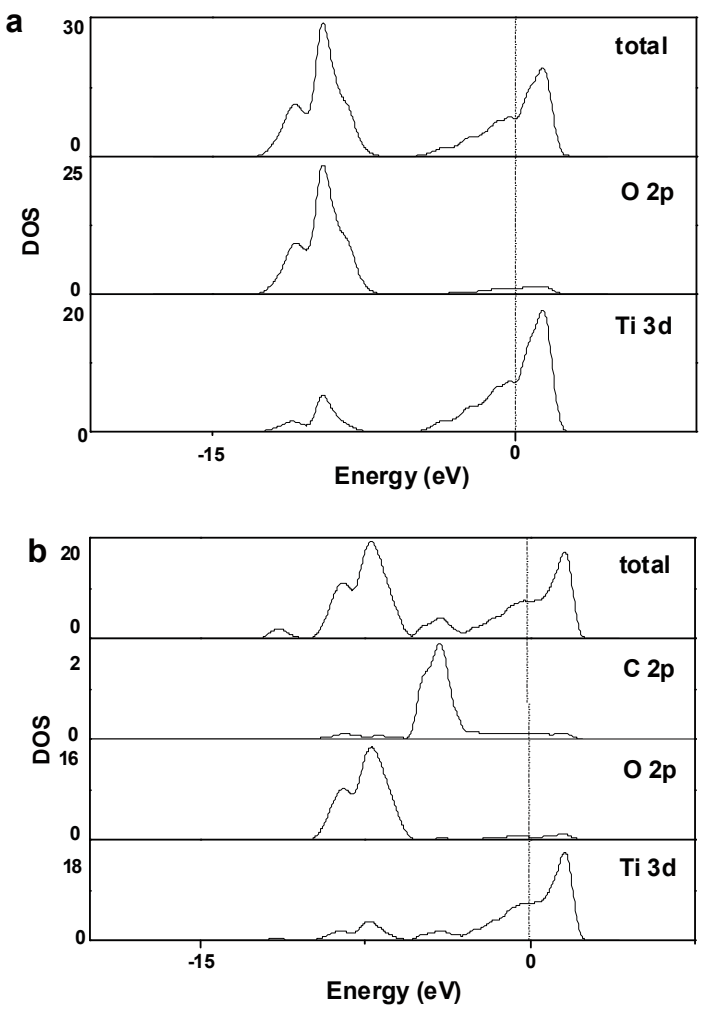

Fig. 7 DOS and PDOS for (a) $\mathrm{TiO}$ and (b) C-doped TiO. 


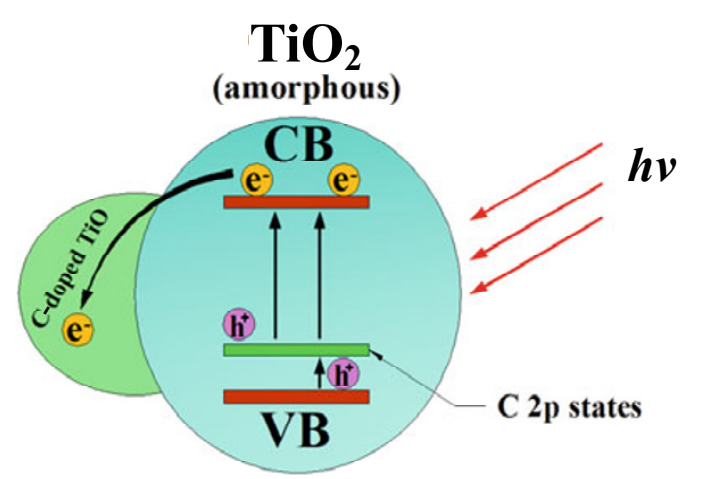

Fig. 8 Photocatalysis mechanism of the as-prepared $\mathrm{C} / \mathrm{Ti}-\mathrm{O}$ film under visible-light irradiation

\section{Conclusions}

In this paper, the $\mathrm{C} / \mathrm{Ti}-\mathrm{O}$ film was prepared by RMS using $\mathrm{CO}_{2}$ gas as carbon and oxygen source. It was confirmed that $\mathrm{C}$ was doped into titanium oxide successfully based on the existence of the typical $\mathrm{Ti}-\mathrm{C}$ bond. The as-prepared $\mathrm{C} / \mathrm{Ti}-\mathrm{O}$ film showed the red shift of absorption edge compared with $\mathrm{P} 25\left(\mathrm{TiO}_{2}\right)$, which contributed to $\mathrm{C}$ substitution in $\mathrm{O}$ sites in amorphous $\mathrm{TiO}_{2}$. Secondly, C-doped $\mathrm{TiO}$ as metal load was confirmed using Materials Studio software based on first principles, which benefitted the separation of electrons and holes and made the $\mathrm{C} / \mathrm{Ti}-\mathrm{O}$ film with $\mathrm{TiO}$ crystal phase exhibit photocatalytic activity.

\section{Acknowledgements}

This work was financially supported by the National Natural Science Foundation of China (Nos. 51062002 and 81171462), National Science Fund of Hainan Province (No. 511113) and Key Project of Science and Technology Planning of Hainan Province (No. ZDXM20110051).

Open Access: This article is distributed under the terms of the Creative Commons Attribution License which permits any use, distribution, and reproduction in any medium, provided the original author(s) and the source are credited.

\section{References}

[1] Linsebigler AL, Lu G, Yates JT. Photocatalysis on $\mathrm{TiO}_{2}$ surfaces: Principles, mechanisms, and selected results. Chem Rev 1995, 95: 735-758.

[2] Azevedo EB, Neto FRA, Dezotti M. $\mathrm{TiO}_{2-}$ photocatalyzed degradation of phenol in saline media: Lumped kinetics, intermediates, and acute toxicity. Appl Catal B: Environ 2004, 54: 165-173.

[3] Baran W, Makowski A, Wardas W. The effect of UV radiation absorption of cationic and anionic dye solutions on their photocatalytic degradation in the presence $\mathrm{TiO}_{2}$. Dyes Pigments 2008, 76: 226-230.

[4] Hashimoto K, Irie $\mathrm{H}$, Fujishima A. $\mathrm{TiO}_{2}$ photocatalysis: A historical overview and future prospects. Jpn J Appl Phys 2005, 44: 8269-8285.

[5] Hung W-C, Fu S-H, Tseng J-J, et al. Study on photocatalytic degradation of gaseous dichloromethane using pure and iron ion-doped $\mathrm{TiO}_{2}$ prepared by the sol-gel method. Chemosphere 2007, 66: 2142-2151.

[6] Li M, Zhang J, Guo D, et al. Band gap engineering of compensated $(\mathrm{N}, \mathrm{H})$ and $(\mathrm{C}, 2 \mathrm{H})$ codoped anatase $\mathrm{TiO}_{2}$ : A first-principles calculation. Chem Phys Lett 2012, 539-540: 175-179.

[7] Fujii $\mathrm{H}$, Inata $\mathrm{K}$, Ohtaki $\mathrm{M}$, et al. Synthesis of $\mathrm{TiO}_{2} / \mathrm{CdS}$ nanocomposite via $\mathrm{TiO}_{2}$ coating on $\mathrm{CdS}$ nanoparticles by compartmentalized hydrolysis of $\mathrm{Ti}$ alkoxide. J Mater Sci 2001, 36: 527-532.

[8] Otaka H, Kira M, Yano K, et al. Multi-colored dye-sensitized solar cells. $J$ Photoch Photobio A 2004, 164: 67-73.

[9] In S, Orlov A, Berg R, et al. Effective visible light-activated $\mathrm{B}$-doped and $\mathrm{B}, \mathrm{N}$-codoped $\mathrm{TiO}_{2}$ photocatalysts. $J$ Am Chem Soc 2007, 129: 13790-13791.

[10] Lee J-Y, Park J, Cho J-H. Electronic properties of Nand C-doped $\mathrm{TiO}_{2}$. Appl Phys Lett 2005, 87: 011904.

[11] Yu Y, Wu H-H, Zhu B-L, et al. Preparation, characterization and photocatalytic activities of F-doped $\mathrm{TiO}_{2}$ nanotubes. Catal Lett 2008, 121: 165-171.

[12] Yang K, Dai Y, Huang B. Understanding photocatalytic activity of S- and P-doped $\mathrm{TiO}_{2}$ under visible light from first-principles. $J$ Phys Chem $C$ 2007, 111: 18985-18994.

[13] Wang X, Meng S, Zhang X, et al. Multi-type carbon doping of $\mathrm{TiO}_{2}$ photocatalyst. Chem Phys Lett 2007, 444: 292-296.

[14] Yang X, Cao C, Erickson L, et al. Synthesis of visible-light-active $\mathrm{TiO}_{2}$-based photocatalysts by carbon and nitrogen doping. J Catal 2008, 260: 128-133.

[15] Ohtani B, Ogawa Y, Nishimoto S. Photocatalytic activity of amorphous-anatase mixture of titanium(IV) oxide particles suspended in aqueous solutions. J Phys Chem B 1997, 101: 3746-3752.

[16] Randorn C, Wongnawa S, Boonsin P. Bleaching of 
methylene blue by hydrated titanium dioxide. ScienceAsia 2004, 30: 149-156.

[17] Zhang Z, Maggard PA. Investigation of photocatalytically-active hydrated forms of amorphous titania, $\mathrm{TiO}_{2} \cdot n \mathrm{H}_{2} \mathrm{O}$. J Photoch Photobio A 2007, 186: 8-13.

[18] Li J, Liu S, He Y, et al. Adsorption and degradation of the cationic dyes over Co doped amorphous mesoporous titania-silica catalyst under UV and visible light irradiation. Microporous Mesoporous Mater 2008, 115: 416-425.

[19] Kanna M, Wongnawa S, Buddee S, et al. Amorphous titanium dioxide: A recyclable dye remover for water treatment. J Sol-Gel Sci Technol 2010, 53: 162-170.

[20] Wang H, Zong Z, Yan Y, et al. First-principles study of ferromagnetism in $\mathrm{N}$ doped $\mathrm{TiO}_{2}$ and TiO. J Magn Magn Mater 2012, 324: 2858-2860.

[21] Zhang Y, Ma X, Chen P, et al. Effect of the substrate temperature on the crystallization of $\mathrm{TiO}_{2}$ films prepared by DC reactive magnetron sputtering. J Cryst Growth 2007, 300: 551-554.

[22] Martin N, Santo AME, Sanjinés R, et al. Energy distribution of ions bombarding $\mathrm{TiO}_{2}$ thin films during sputter deposition. Surf Coat Technol 2001, 138: $77-83$.

[23] Dang BHQ, Rahman M, MacElroy D, et al. Evaluation of microwave plasma oxidation treatments for the fabrication of photoactive un-doped and carbon-doped $\mathrm{TiO}_{2}$ coatings. Surf Coat Technol 2012, 206: 4113-4118.

[24] Cong Y, Li X, Qin Y, et al. Carbon-doped $\mathrm{TiO}_{2}$ coating on multiwalled carbon nanotubes with higher visible light photocatalytic activity. Appl Catal B: Environ 2011, 107: 128-134.

[25] Gu D, Lu Y, Yang B, et al. Facile preparation of micro-mesoporous carbon-doped $\mathrm{TiO}_{2}$ photocatalysts with anatase crystalline walls under template-free condition. Chem Commun 2008: 2453-2455.
[26] Yang J, Bai H, Jiang Q, et al. Visible-light photocatalysis in nitrogen-carbon-doped $\mathrm{TiO}_{2}$ films obtained by heating $\mathrm{TiO}_{2}$ gel-film in an ionized $\mathrm{N}_{2}$ gas. Thin Solid Films 2008, 516: 1736-1742.

[27] Fu Y, Du H, Zhang S, et al. XPS characterization of surface and interfacial structure of sputtered TiNi films on Si substrate. Mat Sci Eng A 2005, 403: 25-31.

[28] Yang J, Dai J, Li J. Synthesis, characterization and degradation of Bisphenol A using Pr, N co-doped $\mathrm{TiO}_{2}$ with highly visible light activity. Appl Surf Sci 2011, 257: 8965-8973.

[29] Suriye K, Praserthdam P, Jongsomjit B. Control of $\mathrm{Ti}^{3+}$ surface defect on $\mathrm{TiO}_{2}$ nanocrystal using various calcination atmospheres as the first step for surface defect creation and its application in photocatalysis. Appl Surf Sci 2007, 253: 3849-3855.

[30] Hamdy MS, Amrollahi R, Mul G. Surface $\mathrm{Ti}^{3+}$ containing (blue) titania: A unique photocatalyst with high activity and selectivity in visible light-stimulated selective oxidation. ACS Catal 2012, 2: 2641-2647.

[31] Kubokawa Y, Anpo M, Yun C. Olefin photooxidation and oxygen anion radicals on oxide surfaces. Stud Surf Sci Catal 1981, 7: 1170-1184.

[32] Anpo M, Chiba K, Tomonari M, et al. Photocatalysis on native and platinum-loaded $\mathrm{TiO}_{2}$ and $\mathrm{ZnO}$ catalysts. Origin of different reactivities on wet and dry metal oxides. B Chem Soc Jpn 1991, 64: 543-551.

[33] Gao H, Ding C, Dai D. Density functional characterization of C-doped anatase $\mathrm{TiO}_{2}$ with different oxidation state. $J$ Mol Struc-THEOCHEM 2010, 944: 156-162.

[34] Li F, Zhao Y, Hao Y, et al. N-doped P25 $\mathrm{TiO}_{2}$-amorphous $\mathrm{Al}_{2} \mathrm{O}_{3}$ composites: One-step solution combustion preparation and enhanced visible-light photocatalytic activity. $J$ Hazard Mater 2012, 239-240: 118-127. 